\title{
Author Correction: Discrepancy in scientific authority and media visibility of climate change scientists and contrarians
}

\author{
Alexander Michael Petersen (10 1, Emmanuel M. Vincent 2,3 \& Anthony LeRoy Westerling 1,3,4
}

Correction to: Nature Communications https://doi.org/10.1038/s41467-019-09959-4, published online 13 August 2019.

The original versions of Fig. 1, Fig. 2 and Fig. 6 in this Article have been updated.

Figure $1 \mathrm{~b}, \mathrm{c}$ have been updated to remove an individual's name and associated data.

Figure $2 \mathrm{c}$ has been updated to anonymize the data.

Figure 6 has been updated to remove individuals' names associated with the light-blue data points in the top-right.

This has been updated in both the PDF and HTML versions of the Article.

Published online: 29 August 2019

\begin{abstract}
(c) (i) Open Access This article is licensed under a Creative Commons Attribution 4.0 International License, which permits use, sharing, adaptation, distribution and reproduction in any medium or format, as long as you give appropriate credit to the original author(s) and the source, provide a link to the Creative Commons license, and indicate if changes were made. The images or other third party material in this article are included in the article's Creative Commons license, unless indicated otherwise in a credit line to the material. If material is not included in the article's Creative Commons license and your intended use is not permitted by statutory regulation or exceeds the permitted use, you will need to obtain permission directly from the copyright holder. To view a copy of this license, visit http://creativecommons.org/licenses/by/4.0/.
\end{abstract}

(C) The Author(s) 2019

\footnotetext{
${ }^{1}$ Management of Complex Systems Department, Ernest and Julio Gallo Management Program, School of Engineering, University of California, Merced, CA 95343, USA. ${ }^{2}$ Medialab, Sciences Po, Paris 75007, France. ${ }^{3}$ Center for Climate Communication, University of California, Merced, CA 95343, USA. ${ }^{4}$ Sierra Nevada Research Institute, University of California, Merced, CA 95343, USA. Correspondence and requests for materials should be addressed to A.M.P. (email: apetersen3@ucmerced.edu) or to E.M.V. (email: mel.manux@gmail.com) or to A.L.W. (email: awesterling@ucmerced.edu)
} 